\title{
Surgical Procedure Details
}

National Cancer Institute

\section{Source}

National Cancer Institute. Surgical Procedure Details. NCI Thesaurus. Code C159286.

A header for a form section about other surgical procedure details. 